\title{
Does the environment matter on the wine market: an analysis of the wine market in Austria
}

\author{
P. Amrusch \& F. Wirl \\ University of Vienna, Austria
}

\begin{abstract}
The main aim of the paper is the estimation of regional and environmental values capitalized in the wine market. By means of hedonic regression analysis, possible premiums attached to nonmarket characteristics such as geographical designations and regional qualities are deferred from the Austrian wine market prices. Moreover, the relation between land values and wine prices is addressed. In the introductory section the main legal changes in the Austrian wine market are pointed out. Afterwards, the variable selection of perceived price signals on the basis of the assumption of homogeneity of wine consumers' preferences of regulations underlying the model is performed. Finally, the hedonic regressions display the consumers 'willingness to pay for various wine characteristics, whereby the relevance of geographical designations and other regional criteria reflected in the land values are investigated. Finally, possible future implications of the results are highlighted.

Keywords: hedonic modelling, estimation of non-market value, Austrian wine market, valuation of vineyards, willingness-to-pay for geographical designation.
\end{abstract}

\section{Introduction}

In this paper, premiums attached to nonmarket values reflected in the wine prices are estimated. By means of hedonic regression analyses traced back to Rosen [1] and Freeman [2] the relation between environmental characteristics and wine prices is assessed.

Several studies evaluate the impact of location factors on selling prices for vineyards. For instance, Cross et al. [4] shows that the value of terroir of vineyards is significantly influenced by location-specific criteria. 
On the other hand, it is generally known that the quality of grapes is related to the quality of soil and land.

Mees et al. [5] suggest that the quality of agricultural land is positively correlated to the grape quality. Ashenfelter and Storchmann [6] show the impact of climate on agricultural land also considering factors improving the suitability of sites for the production of grapes. Literature suggests that consumers of wine attach a premium to certified wine (e.g. Rabkin and Beatty [7]).

One main purpose of the paper is to estimate non-market goods and services on the wine market. Thereby, the objective of this paper is the evaluation of impact of location-specific and environmental criteria on the selling price of wine. Additionally, the relation between wine market characteristics and land values are addressed.

\section{The Austrian wine market}

In Austria there are around 6,500 produces (holdings) of around 5 types of wine (based on personal communication by wine sellers).

The wine harvest survey 2011 by Statistics Austria [3] displayed a wine production of 2,814,800 hl, produced on an area of 43,800 ha. In 1999 Statistic Austria classified the Austrian wine production areas into four main wine regions, the Weinland (comprising Burgenland, Lower Austria), the Steirerland (comprises Styria), the Bergland (comprises: Carinthia, Upper Austria, Salzburg, Tyrol, Vorarlberg) and Vienna; in the Weinland the highest number of holdings exists $(17,184)$ on an area of around $41,069,97$ hectares. In the Steirerland there are 2,479 holdings with vineyards of 3,876.26 hectares and the city of Vienna has 379 holdings are on an area of 557.19 hectares.

The smallest number of vineyard holders is in the mountainous parts of Austria, the Bergland, with 139 vineyard holders on an area of 82.38 hectares; in 1999 around $70 \%$ of the wine produced was white and 30\% was red wine [3].

\subsection{Legal regulations}

According to Schamel [8], wine quality is not only determined by consumer's tastes, but also by the definition of quality through regulations: in addition to "any expert appraisal of sensory based on subjective impressions, wine quality is also classified according to legally binding criteria and standards that are measurable and verifiable".

Based on the regulation European Union Wine Market Regulation [9] effective on the $1^{\text {st }}$ August 2009 the indication of provenience of wine designations of origin and geographical indications of wine became central aspects in the valuation of wine quality.

From the $1^{\text {st }}$ of August 2009 the "EU Member States can impose more stringent restrictions for wines produced on their territory in order to preserve the essential characteristics of wines with a protected designation of origin or a protected geographical indication, and of sparkling wines and liqueur wines" (European Union [9]). "One purpose of the rules on designations of origin, 
geographical indications and traditional terms is the protection of interests of consumers and producers and promotion of the production of high-quality products" (European Union [9]).

Historically, in the European Union two main wine classification systems developed: The roman system wine quality was traditionally associated with the origin of production of wine (such as Rioja, Champagne, Frascati). On the other hand, the Germanic system wine quality is mainly associated with physiological characteristics of grapes, whereby the wine was usually branded on the basis of type of wine or the producer's name [15]. Consequently, the introduction of a classification system relying on the designation of origin is not historically rooted in Austria, for which reason the Austrian wine consumers orient themselves to grape sort and quality (e.g., Zweigelt, Grüner Veliner).

\section{Empirical part}

The hedonic technique is commonly applied in order to assess the willingness to pay for market and non-market characteristics capitalized in market values, based on a couple of assumptions. In this paper, the hedonic pricing method is used to estimate the value of nonmarket values capitalized in the price of wine, Hereby, wine and location-specific characteristics as independent variables are regressed on the price of white wine, in view of the theory underlying the hedonic model.

\subsection{Data}

Skuras and Vakrou [10] show by means of the Contingent Valuation Method that wine consumers' willingness to pay varies no more than according to social and demographic characteristics. In this study, on the basis of the results by Skuras and Vakrou [10] two (online) wine shops were chosen with higher-grade wine in order to exclude consumers preferring lower wine quality (which usually buy the low-quality wine in a discount market), since the hedonic model is based on the assumption of homogeneity of preferences (e.g. Turner [11]).

The data on wine selling prices per litre, denoted by $\mathrm{P} / \mathrm{l}$, along with wine characteristics, were provided by two Austrian wine sellers with a large range of wine types (www.wein-handel.at, http://www.weinco.at/) in 2012. The lowest price of wine per litre in the sample is $€ 4.95$; the median wine costs per litre costs $€ 17$, the maximum wine price per litre of about $€ 500$ is due to the oldest wine in the sample.

In general, in hedonic modelling, perceived values (subjective values) should preferably be applied rather than measured (objective) values. All information about wine characteristics is gained from the wine description and explanations along with the price data.

However, the use of quality signals (due to wine competitions or geographical designations) in describing wine quality implies that buyers and sellers of wine are less informed about the attributes of a vineyard and the wine, for which reason the market relies on quality signals (Cross et al. [4]). Hence, in addition, 
data on wine rankings used in Austria (using points at contests organised by the journal Falstaff [17]) determined by were collected.

Along with all the wine characteristics influencing the taste of wine, such as the type of wine (i.e. red, white, dry, sweet, partially dry, temperature in ${ }^{\circ} \mathrm{C}$, alcohol content in \% (denoted by ALC), sugar content and acidity in g/l) also the type of soil of a specific vineyard was available (i.e. chalky soil, shell lime stone, highland) from the wine sellers. Further wine attributes were related to the storage, such as steel storage cylinder, wooded wine barrel, barrique wine barrel, partially barrique wine barrel and the material of the bottle top (i.e. glass). Dummy variables take on the value 1 for red $\left(D^{\text {red }}\right)$, white $\left(D^{\text {white }}\right)$, dry $\left(D^{\text {dry }}\right)$, sweet $\left(D^{\text {sweet }}\right)$, partially dry wine $\left(D^{\text {pdry }}\right)$, for the case of a partially barrique barrel $\left(D^{\text {pbarrique }}\right)$ or a barrique barrel $\left(D^{\text {barrique }}\right)$, a wooden wine barrel $\left(D^{\text {wood }}\right)$, the material of the bottle top (cork, glass, etc.), otherwise zero.

In addition, data on each winery were traced back in order to determine the exact postal code of the wine production area. Complementarily, medium land value prices (of construction land) per square metre per postal code are gained by the data published yearly in the Austrian monthly journal, Der Gewinn [12]. It is to be noted that agricultural land values are generally lower than construction land values, since the valuation of agricultural land is based on future earnings, i.e. see Bastian et al. [13]. In this paper a positive correlation between land values and construction values per postal code is assumed.

\subsection{Geographical designation as price signal of wine}

Cross et al. [4] show that buyers and sellers of vineyards in Oregon attach a significant premium to geographical designations allowing for the identification of the geographical origin of grapes.

In Austria, the term geographical designation was recently introduced on the basis of regulation mentioned in the introductory section.

The notion of geographical designation is still new for consumers and sellers (as well as producers) of wine. In 2002 in Austria the "Districtus Austriae Controllatus" (DAC [14]) was introduced comprising at the moment seven wine regions (or eight DACs), however, the traditional wine quality indications criteria (such as that of grapes) still remain part of wine the wine specification. It is to be noted that not all wine producers in these wine regions make use of the designation DAC up to now.

For that reason, also a dummy variable (defined by DAC) standing for the 7 DAC-regions was created (Kremstal, Kamptal, Traisental, Mittelburgenland, Südburgenland (including mainly the region Eisenberg), Neusiedlersee, Weinviertel, taking on the value one if the vineyard is in the DAC-region. Furthermore, 16 dummy variables for every specific wine region (there are 16 regions in total) were constructed, taking on the value 1 if the wine is produced in the specific geographical site, otherwise zero, denoted by $\mathrm{D}^{\text {Wien }}$ (Wien), $\mathrm{D}^{\mathrm{Kr}}$ (Krems), $D^{\text {Tr }}$ (Traisental), $D^{\text {Mitt }}$ (Mittelburgenland), $D^{\text {Neu }}$ (Neusiedlersee) $D^{\text {Wv }}$ (Weinviertel), $\mathrm{D}^{\mathrm{NH}}$ (Neusiedlersee Hügelland) $\mathrm{D}^{\text {Wac }}$ (Wachau), $\mathrm{D}^{\text {Süds }}$ (Südsteiermark) $\mathrm{D}^{\text {Südo }}$ (Südoststeiermark) $\mathrm{D}^{\text {Wests }} \quad$ (Weststeiermark) $\mathrm{D}^{\text {Süd }}$ (Südburgenland) $\mathrm{D}^{\text {Wag }}$ (Wagram), $\mathrm{D}^{\text {Ther }}$ (Thermenregion), $\mathrm{D}^{\text {Car }}$ (Carnuntum). 
The construction land values per square metre, denoted by $\mathrm{P} 1$, and the variable for the DAC-regions, denoted by DAC, are negatively correlated, also excluding the region Vienna (the wine area of the capital of Austria) from the sample due to the higher land values in the capital of Austria.

\subsection{Estimation of the willingness to pay for non-market and market characteristics}

First, to control for multicollinearity, highly correlated variables were detected. The choice of functional form of the OLS-regression is based on the expected relationship between the independent variables and the selling price of wine as well as on model selection criteria by testing frequently used functional forms.

Table 1: $\quad$ Hedonic model.

\begin{tabular}{|c|c|}
\hline Constant and variables & Coefficients (with absolute t-parentheses) \\
\hline Constant & $\begin{array}{c}-5.019349 \\
(5.2) \\
\end{array}$ \\
\hline $\operatorname{Ln}(\mathrm{P} 1) * \mathrm{D}^{\text {white }} *(1-\mathrm{DAC})$ & $\begin{array}{r}0.640668 \\
(24.4) \\
\end{array}$ \\
\hline $\mathrm{D}^{\text {wood }} * \mathrm{D}^{\text {white }}$ & $\begin{array}{c}0.807332 \\
(6.7)\end{array}$ \\
\hline $\operatorname{Ln}\left(\mathrm{ALC} * \mathrm{D}^{\text {white }}\right)$ & $\begin{array}{c}2.060169 \\
(5.5)\end{array}$ \\
\hline DAC $* D^{\text {white }}$ & $\begin{array}{r}2.374303 \\
(30.5) \\
\end{array}$ \\
\hline $\mathrm{D}^{\text {Wien }} * \mathrm{D}^{\text {white }}$ & $\begin{array}{c}-1.105810 \\
(4.6)\end{array}$ \\
\hline $\mathrm{D}^{\text {pbarrique } *} \mathrm{D}^{\text {white }}$ & $\begin{array}{r}0.862867 \\
(11.3) \\
\end{array}$ \\
\hline $\mathrm{D}^{\text {Wag }} * \mathrm{D}^{\text {white }}$ & $\begin{array}{r}-0.466367 \\
(2.9)\end{array}$ \\
\hline \multicolumn{2}{|c|}{$\mathrm{N}=298, \mathrm{R}^{2}=0.82, \mathrm{R}^{2}$ adj. $=0.82, \mathrm{JB}=8.5$, Dep. Variable $=\mathrm{Ln}(\mathrm{P} / 1)^{*} \mathrm{D}^{\text {white }}$} \\
\hline
\end{tabular}

Wang and Wolverton [16] found that a regression model with a low $\mathrm{R}^{2}$ from a uniform sample could give a better price prediction than a model with more explanatory power estimated from a more heterogeneous sample. For this reason, and in line with Rabkin and Beatty [7], in running the OLS-regression all selected variables were multiplied by the dummy variable $\mathrm{D}^{\text {white }}$ taking on the value one if the wine is white and zero otherwise. By using a set of 298 observations 
( $\mathrm{N}=298$ ), the log-log-specification was found to fit best the data set explaining about $82 \%$ of the variance of $\ln$ (price/litre)* $\mathrm{D}^{\text {white }}$.

Due to the low value of Jarque-Bera $(\mathrm{JB}=8.47)$ no deviation from normality of residuals is assumed in the regression.

By using White's heteroskedasticity-consistent estimates, in Table 1 all coefficients are highly significant (at least at a 0.95 confidence interval).

The hedonic regression results display that the regional dummies, the manner of wine storage, the alcohol content as well as the dummy DAC have a significant impact on the white wine selling price in $€$. Consumers of white wine are disposed to pay about 10 times more (around 974\%) for one litre of white wine from DAC-regions in comparison to white wine from other wine areas.

However, only two other non-DAC regions are significantly negatively correlated with the price of white wine (Vienna, Wagram) per litre in comparison to wine produced in other wine regions.

Furthermore, results reveal a significant relationship between manner of storage of white wine and the price/litre. For white wine stored in wooden barrels or (partially) barrique barrels, consumers are willing to pay about $124 \%$ more in contrast to white wine stored in a different or unknown manner. A onepercent increase of alcohol content implies that price of white wine per litre goes up about $2 \%$.

Interestingly, there is also a positive relationship between the medium (construction) land value and the price of white wine per postal code (ZIP). One plausible explanation would be that a higher valued land fosters also the quality of grapes, since the quality of soil plays a central role in wine production.

Contrarily, it could to be found out whether the existence of vineyards may have positive overall appearance of the landscape and on the overall land values of the region.

\section{Summary results and future research}

Results indicate that the origin of the wine produced plays a significant role on the Austrian wine market. Denominations of origin may display quality signals for consumers. Not all non-denominated wine regions in the sample, however, are negatively correlated to the price of white wine.

In view of the German wine valuation system used in Austria, it should be furthermore investigated into more detail whether consumers are indeed willing to pay a premium for white wine produced in DAC regions or a mark-up for certified wine, respectively. In particular due to the geographical variability of the production of specific grapes, it should be examined whether consumers are willing to pay for white wine produced in DAC regions due to the quality signal of DAC, the wine region per se or based on location-specific grape qualities/sorts of white wine. On the basis of the results we summarize that in addition to the origin of the wine (also presumably related to the regional grape qualities) also the soil quality of the vineyard; the manner of storage of wine influences the consumers' willingness to pays for white wine in Austria. 
Results are not only of great importance for producers and sellers of wine, but also for regional marketing activities of regions. Besides, the significant relationship between land values and the wine prices found in the hedonic regression could be a further starting point of future investigations.

\section{References}

[1] Rosen, S., Hedonic Prices and Implicit Markets: Product Differentiation in Pure Competition, Journal of Political Economy 82, pp. 34-55, 1974.

[2] Freeman, A.M., III., On Estimating Air Pollution Control Benefits from Land Value Studies. Journal of Environmental Economics and Management 1 (1), 74-83, 1974.

[3] http://www.statistik.at/ (20.2.2013).

[4] Cross, R., Plantinga, A.J. and Stavins, R.N. What Is the Value of Terroir? American Economic Review: Papers \& Proceedings, 101 (3), 152-156, 2011.

[5] Mees, L., Nagel, K-L., Puhle, K-L. Kampf um den Wein: Modernisierung und Interessenpolitik im spanischen Weinbau, Oldenbourg, Manz Crossmedia, p.169-170, 2005.

[6] Ashenfelter, O.C. and Storchmann K., Using a Hedonic Model of Solar Radiation to Assess the Economic Effect of Climate Change: The Case of Mosel Valley Vineyards CEPS Working Paper No. 130, July 2006.

[7] Rabkin, E.D. and Beatty, K.M.T., Does VQA Certification Matter? A Hedonic Analysis. Canadian Public Policy - Analyse de Politiques, Vol. XXXIII, NO. 32007.

[8] Schamel G., A Hedonic Pricing Model for German Wine. Ein hedonisches Preismodell für Qualitätswein aus Deutschland, Agrarwirtschaft 52, Heft 5, 2003, pg. 247ff.

[9] European Union: http://europa.eu/legislation_summaries/agriculture/ agricultural products markets/ag0001 en.htm (20.2.2013).

[10] Skuras, D. and Vakrou, A. Consumers' willingness to pay for origin labelled wine: A Greek case study, British Food Journal, Vol. 104 (11), pp. $898-912,2002$.

[11] Turner R. K., Sustainable Environmental Economics and Management: Principles and Practice, London pp. 120, 226, 1993.

[12] Der Gewinn: www.gewinn.com (20. 2. 2013).

[13] Bastian, C.T., McLeod, D.M., Germino, M.J, Reiners, W. A. and Blasko, B.J., Environmental amenities and agricultural land values: a hedonic model using geographic information systems data, Ecological Economics, Volume 40, Issue 3, Pages 337-349, 2002.

[14] The new Appellation wines in Austria ( DAC) http://www.austrianwine .com/our-wine/the-new-appellation-wines-in-austria-dac/ (20. 2. 2013).

[15] Ordo Equestris Vini Europae, Consulat Steiermark, Weininformation, Jänner, Februar, 2012. 
[16] Wang, K.W. and Wolverton M. L., Real Estate Valuation Theory, Appraisal Institute and American Real Estate Society, Kluwer Academic Publishers, 2002.

[17] Bentzen, J. and Smith, V., Wine production in Denmark "Do the characteristics of the vineyards affect the chances for awards?," Working Papers 09-21, University of Aarhus, Aarhus School of Business, Department of Economics, 2009. 